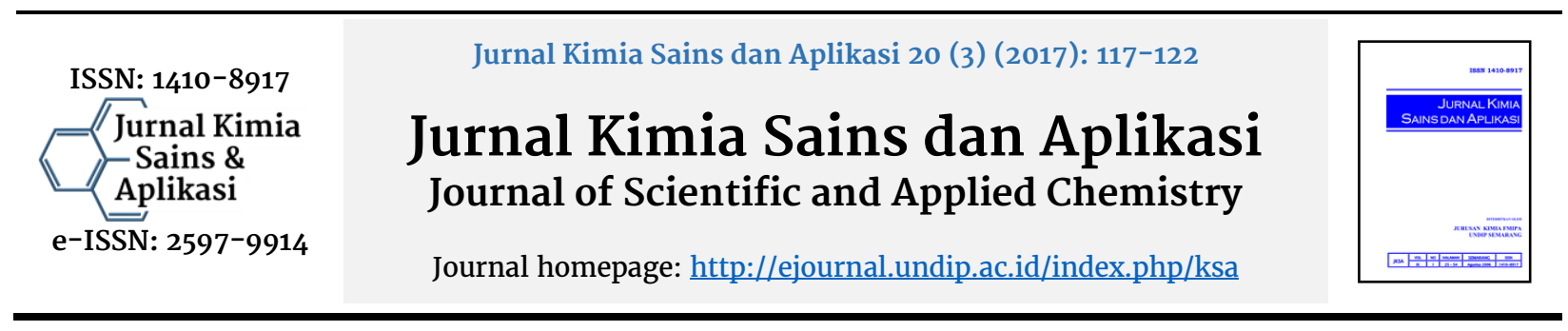

\title{
Triterpenoid dan Nanopartikel Ekstrak n-Heksana dari Rimpang Lengkuas Merah (Alpinia purpurata (Vieill.) K. Schum) Serta Uji Sitotoksisitas dengan BSLT
}

\author{
Dian Nopitasari ${ }^{\mathrm{a}^{*}}$, Enny Fachriyah ${ }^{\mathrm{a}}$, Pratama Jujur Wibawa ${ }^{\text {a }}$ \\ a Organic Chemistry Laboratory, Chemistry Department, Faculty of Sciences and Mathematics, Diponegoro University, Jalan Prof. \\ Soedarto, Tembalang, Semarang 50275 \\ * Corresponding author: dianopitasari25@gmail.com
}

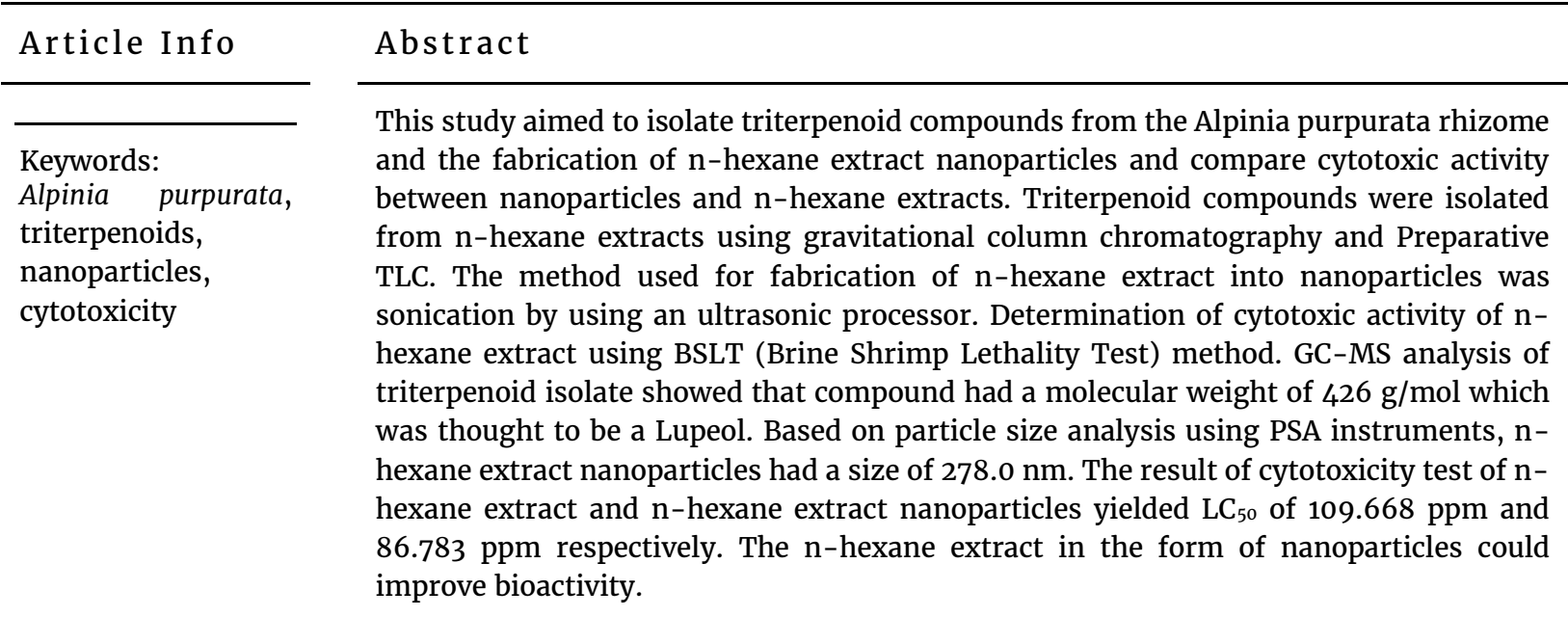

\section{Abstrak}

Kata kunci: Alpinia purpurata, triterpenoid, nanopartikel, sitotoksisitas

\begin{abstract}
Penelitian ini bertujuan untuk mengisolasi senyawa triterpenoid dari rimpang Alpinia purpurata dan fabrikasi nanopartikel ekstrak $n$-heksana serta membandingkan aktivitas sitotoksik antara nanopartikel dan ekstrak $n$-heksana. Senyawa triterpenoid diisolasi dari ekstrak $n$-heksana menggunakan kromatografi kolom gravitasi dan KLT Preparatif. Metode yang digunakan untuk fabrikasi ekstrak $n$-heksana menjadi nanopartikel adalah sonikasi dengan menggunakan prosesor ultrasonik. Penentuan aktivitas sitotoksik ekstrak n-heksana menggunakan metode BSLT (Brine Shrimp Lethality Test). Hasil analisis GC-MS isolat triterpenoid memiliki berat molekul sebesar $426 \mathrm{~g} / \mathrm{mol}$ diduga merupakan senyawa Lupeol. Berdasarkan analisis ukuran partikel menggunakan instrumen PSA, nanopartikel ekstrak n-heksana memiliki ukuran 278,0 nm. Hasil uji sitotoksisitas ekstrak $n$-heksana dan nanopartikel ekstrak $n$-heksana menghasilkan LC $_{50}$ berturut-turut sebesar 109,668 ppm dan 86,783 ppm. Ekstrak n-heksana dalam bentuk nanopartikel dapat meningkatkan bioaktivitas.
\end{abstract}

\section{Pendahuluan}

Indonesia merupakan negara yang berada di kawasan tropis yang memiliki kekayaan alam berupa tanaman yang dapat digunakan sebagai obat. Salah satu tanaman tersebut adalah lengkuas merah. Tanaman lengkuas termasuk dalam genus Alpinia, merupakan genus terbesar yang memiliki taksonomi paling kompleks pada famili Zingiberaceae [1]. Berdasarkan penelitian etnobotani, spesies Alpinia telah banyak dimanfaatkan sebagai bahan obat-obatan di negara Asia [2]. A. purpurata memiliki aktivitas sebagai antioksidan, 
antibakteri, larvasida, sitotoksik dan vasodilator [3]. Kandungan metabolit sekunder dalam lengkuas merah adalah flavonoid, alkaloid, tanin, triterpenoid/steroid, dan saponin [4]. Penelitian mengenai triterpenoid dalam lengkuas merah masih sedikit dilakukan. Hal ini ditandai dengan publikasi yang masih sulit ditemukan, baik berupa jurnal maupun buku sehingga triterpenoid dari rimpang lengkuas merah dipilih dalam penelitian ini.

Nanopartikel merupakan suatu partikel berukuran 1-100 nm yang memiliki sifat-sifat bioaktivitas yang unggul dan unik jika dibandingkan dengan ukuran bulk nya [5]. Dalam konteks ini, sifat bioaktivitas senyawa diharapkan akan meningkat ketika berukuran nanopartikel. Penelitian Yariv dkk. [6] melaporkan bahwa aktivitas antibakteri penisilin sebelum dan sesudah berukuran nano meningkat. Fabrikasi nanopartikel dilakukan menggunakan metode sonikasi. Sedangkan penentuan aktivitas antioksidan vitamin B menggunakan metode Electron paramagnetic spectroscopy dihasilkan nanopartikel vitamin B memiliki aktivitas antioksidan lebih besar dibandingkan vitamin B bentuk bulk nya [6]. Hal ini menunjukkan bahwa metode sonikasi dapat memfabrikasi nanopartikel, dan dapat meningkatkan sifat bioaktivitasnya. Pembuatan nanopartikel ekstrak $n$-heksana rimpang lengkuas merah belum pernah dilakukan, sehingga pada penelitian ini akan dilakukan fabrikasi nanopartikel dengan harapan untuk meningkatkan sifat bioaktivitasnya. Nanopartikel ekstrak $n$-heksana yang dihasilkan dengan menggunakan metode sonikasi akan diuji aktivitas sitotoksiknya.

\section{Metode Penelitian}

\section{Alat dan Bahan}

Peralatan yang digunakan adalah alat gelas standar penelitian, lampu UV $254 \mathrm{~nm}$ dan $365 \mathrm{~nm}$, satu set alat maserasi dan rotary evaporator Buchii, satu set alat penetasan telur Artemia salina, neraca analitik, botol vial, kolom kromatografi, chamber KLT, pipet tetes, pipa kapiler, GC-MS (Gas Chromatography-Mass Spectrometer) QP2010S Shimadzu, prosesor ultrasonik dan PSA (Particle Size Analyzer) Horiba SZ-100.

Bahan yang digunakan dalam penelitian ini adalah serbuk rimpang lengkuas merah, $n$-heksana teknis, pereaksi Libermann-burchard, pelarut pro analysis p.a (Merck) seperti kloroform, $n$-heksana, etil asetat, dan diklorometana, silika gel 60 , plat KLT silika gel $\mathrm{GF}_{254}$ (Merck), plat KLT peparatif silika gel $\mathrm{GF}_{254} 20 \times 20 \mathrm{~cm}$ tebal 2,0 mm (Merck), garam krosok, tween 20, telur Artemia salina, aquabides dan virgin coconut oil (VCO).

\section{Persiapan Bahan}

Sampel penelitian ini adalah rimpang lengkuas merah yang diperoleh dari daerah Jepara. Sebanyak 20 $\mathrm{kg}$ rimpang lengkuas merah dibersihkan dengan air untuk menghilangkan pengotor-pengotor kemudian dikeringkan dengan cara diangin-anginkan, dan dihaluskan hingga menjadi serbuk.

\section{Skrining Fitokimia}

Serbuk rimpang lengkuas merah dilakukan skrining fitokimia yaitu uji steroid/triterpenoid, flavonoid, saponin, alkaloid, dan tannin [7].

\section{Uji Triterpenoid dan Steroid}

Serbuk rimpang lengkuas merah sebanyak 5 gram dimaserasi dengan $20 \mathrm{~mL}$ eter selama 2 jam, kemudian disaring. Selanjutnya $5 \mathrm{~mL}$ filtrat diuapkan dalam cawan penguap sampai kering. Kemudian diberi 2 tetes anhidrida asam asetat dan 1 tetes asam sulfat pekat. Terbentuknya warna biru/hijau menunjukkan adanya steroid sedangkan terbentuknya warna merah/ungu menunjukkan adanya triterpenoid.

\section{Isolasi Triterpenoid}

Serbuk rimpang lengkuas merah sebanyak $2 \mathrm{~kg}$ dimaserasi dengan n-heksana, diuapkan hingga didapatkan ekstrak n-heksana dan ditimbang. Terhadap ekstrak $\mathrm{n}$-heksana dilakukan uji triterpenoid dengan menggunakan pereaksi Libermann-Burchard.

\section{Pemisahan Triterpenoid}

Pemisahan triterpenoid dari ekstrak n-heksana dilakukan dengan metode kromatografi kolom gravitasi. Untuk menentukan eluen yang cocok, dilakukan pemisahan dengan KLT terhadap ekstrak n-heksana menggunakan berbagai eluen. Ekstrak kemudian dipisahkan dengan kromatografi kolom. Fraksi-fraksi yang didapatkan kemudian dilakukan KLT dan fraksi dengan pola noda yang sama digabungkan. Fraksi gabungan diuji triterpenoid dengan KLT berbagai eluen dan disemprot dengan pereaksi Libermann-Burchard. Fraksi yang mengandung triterpenoid dipisahkan dengan KLT Preparatif. Pita yang dominan dikerok dan dilarutkan dengan pelarut yang sesuai. Pelarut kemudian diuapkan hingga dihasilkan kristal dan ditimbang.

\section{Uji Kemurnian}

Senyawa Triterpenoid yang didapatkan dari KLT preparatif diuji kemurnian dengan KLT berbagai eluen dan KLT dua dimensi menggunakan berbagai eluen. Noda tunggal yang terbentuk menunjukkan bahwa isolat triterpenoid telah murni.

\section{Karakterisasi dan Analisis Triterpenoid}

Karakterisasi struktur triterpenoid dianalisis menggunakan Gas Chromatography-Mass Spectrometer (GC-MS).

\section{Fabrikasi Nanopartikel Ekstrak n-heksana}

Ekstrak n-heksana sebanyak 10 mg ditambahkan 6 $\mathrm{mL}$ aquabides dan 1 tetes VCO kemudian diultrasonikasi menggunakan prosesor ultrasonik dengan tegangan 220 volt, daya 50 watt, dan frekuensi $40 \mathrm{KHz}$ selama 30 menit. Analisis nanopartikel ekstrak n-heksana dilakukan menggunakan PSA (Particle Size Analyzer). 
Uji Sitotoksisitas [8]

Untuk menguji aktivitas sitotoksik ekstrak nheksana dan nanopartikel ekstrak n-heksana digunakan metode BSLT. Sebanyak 38 gram garam krosok ditambahkan 1 liter aquades, kemudian disaring dan ditempatkan dalam aquarium yang terbagi menjadi 2 bagian (gelap dan terang). Pada bagian gelap aquarium ditambahkan telur Artemia salina. Larva Artemia salina siap digunakan dalam umur 2 hari. Dibuat larutan ekstrak n-heksana dan nanopartikel ekstrak n-heksana dengan konsentrasi 1000 ppm, 100 ppm dan 10 ppm. Masing-masing larutan dimasukkan ke dalam botol vial , kemudian ditambahkan 10 ekor larva Artemia salina dan diletakkan di bawah penerangan selama 24 jam kemudian diamati kematian larva Artemia salina.

\section{Hasil dan Pembahasan}

\section{Skrining Fitokimia Rimpang Lengkuas Merah}

Dari penelitian dilakukan skrining fitokimia terhadap rimpang lengkuas merah yang memberikan hasil positif terhadap senyawa metabolit sekunder yaitu steroid, triterpenoid, alkaloid, flavonoid, tanin, dan saponin. Sedangkan ekstrak n-heksana memberikan hasil positif terhadap triterpenoid dan steroid. Menurut Oirere dkk. [4] kandungan metabolit sekunder Alpinia purpurata adalah flavonoid, alkaloid, tanin, triterpenoid, steroid, dan saponin.

\section{Isolasi Triterpenoid}

Ekstrak n-heksana yang didapatkan setelah maserasi menggunakan n-heksana dan diuapkan menggunakan rotary evaporator dihasilkan ekstrak nheksana sebesar 15,56 gram (0,78\%) dengan warna ekstrak kuning kecoklatan. Setelah didapatkan ekstrak n-heksana selanjutnya dilakukan uji triterpenoid dengan menggunakan pereaksi Libermann-Burchard untuk memastikan kandungan triterpenoid yang ada dalam ekstrak $n$-heksana rimpang lengkuas merah. Hasil uji ekstrak n-heksana dengan pereaksi Libermannburchard menghasilkan warna merah, hal ini menunjukkan ekstrak $n$-heksana mengandung senyawa triterpenoid.

\section{Pemisahan Triterpenoid}

Ekstrak n-heksana dilakukan uji KLT dengan berbagai eluen organik tunggal maupun campuran seperti kloroform, $n$-heksana, etil asetat, dikorometana, benzena dan campuran berbagai eluen dengan perbandingan tertentu. Hal ini untuk mengetahui jumlah komponen dan mencari eluen terbaik yang akan menjadi dasar pemisahan senyawa dalam kromatografi kolom gravitasi. Berdasarkan hasil KLT dari berbagai eluen belum dihasilkan pemisahan noda yang baik, sehingga dalam kromatografi kolom gravitasi menggunakan eluen dengan gradien kepolaran dari non polar ke polar. Eluen yang digunakan dimulai dari $n$ heksana, kloroform dan etil asetat. Pemisahan senyawa triterpenoid dari ekstrak n-heksana menggunakan kromatografi kolom gravitasi menghasilkan 275 fraksi kecil yang masing-masing ditampung dalam botol vial $15 \mathrm{~mL}$. Dari pengelompokkan fraksi kecil diperoleh 6 fraksi besar dengan pola noda yang berbeda yaitu A, B, C, D, E, dan F.

Identifikasi triterpenoid dilakukan terhadap fraksi A-F dengan menggunakan penampak bercak Libermann Burchard. Terhadap 6 fraksi (A, B, C, D, E, dan F) hasil kolom dilakukan uji triterpenoid dengan disemprotmenggunakan reagen Libermann Burchard kemudian dipanaskan selama beberapa menit maka akan tampak noda berwarna ungu ditunjukkan pada gambar.1.

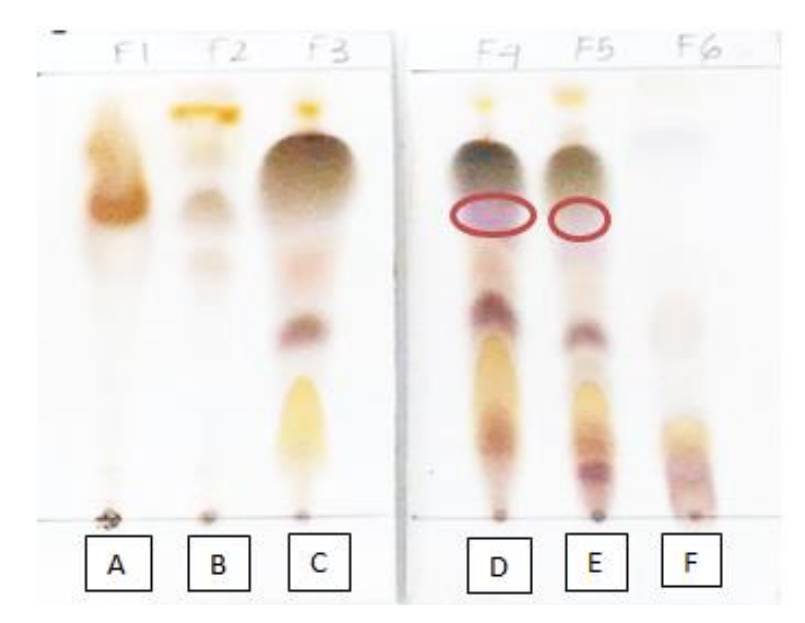

Gambar 1. Hasil uji triterpenoid fraksi besar A, B, C, D, $\mathrm{E}$, dan $\mathrm{F}$ setelah disemprot reagen $\mathrm{LB}$ dengan eluen kloroform tampak visual

Berdasarkan hasil yang diperoleh, terlihat bahwa fraksi D dan E memberikan warna noda ungu sehingga fraksi tersebut positif mengandung triterpenoid. Fraksi $\mathrm{D}$ dan E kemudian digabungkan menjadi fraksi $\mathrm{T}$, tahap selanjutnya adalah dilakukan isolasi triterpenoid dengan menggunakan KLT preparatif. Hasil KLT preparatif fraksi T menggunakan eluen kloroform: nheksana (9:1) disajikan pada gambar 2.

Fraksi $\mathrm{T}$ yang positif mengandung senyawa triterpenoid yaitu pada kemudian dipisahkan dengan KLT preparatif menggunakan eluen kloroform : nheksana (9:1). Hasil KLT preparatif dapat dilihat pada gambar 2.

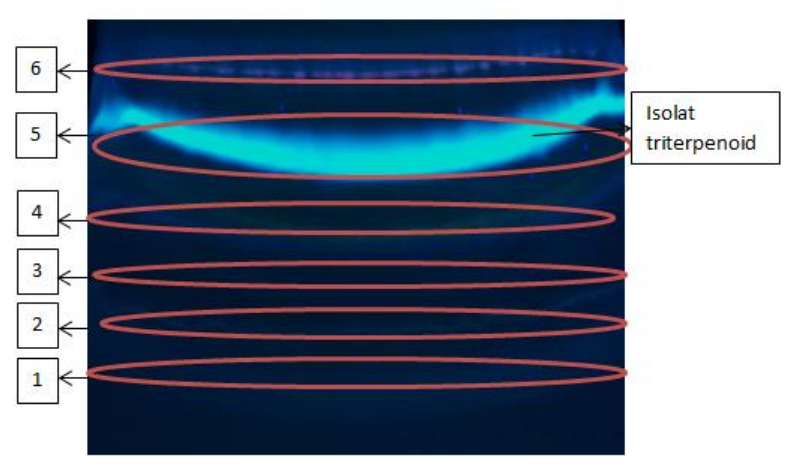

Gambar 2. Hasil KLT Preparatif fraksi T dengan eluen kloroform : n-heksana (9:1) pada lampu uv 365 nm

Dari hasil KLT Preparatif diperoleh 6 pita, pita yang positif mengandung triterpenoid terdapat pada pita 5 (Rf 0,74 ) selanjutnya dikerokan. Silika hasil pengerokan 
dilarutkan dalam kloroform, disaring dan diuapkan sehingga didapatkan isolat triterpenoid. Setelah didapat isolat triterpenoid selanjutnya dilakukan uji kemurnian pita 5. Dari hasil pengujian dihasilkan 2 noda yang menandai bahwa pita 5 belum murni. Pita 5 dipisahkan kembali dengan KLT preparatif menggunakan eluen kloroform : diklorometana ( $3: 7$ ) yang hasilnya dapat dilihat pada gambar 3 .

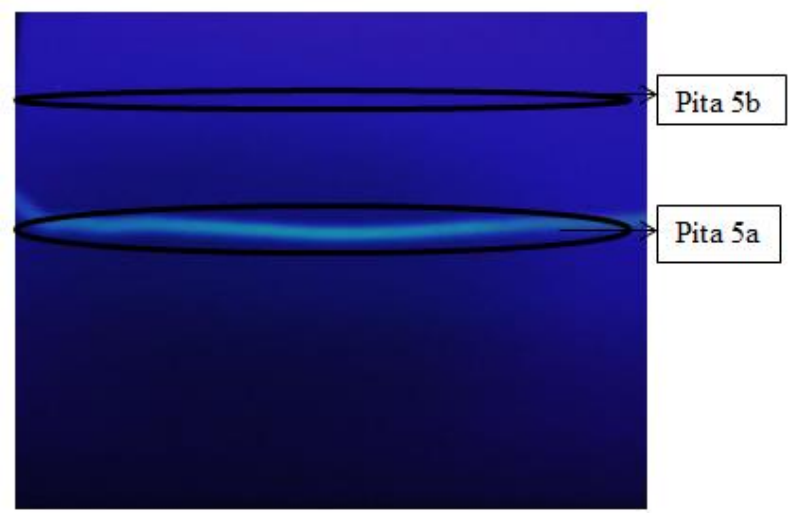

Gambar 3. Hasil KLT Preparatif pita 5 dengan eluen kloroform: diklorometana ( $3: 7)$ pada lampu uv $365 \mathrm{~nm}$

Hasil pemisahan ini diperoleh dua pita yang telah terpisah dengan baik yang teramati pada lampu uv 365 nm, dari kedua pita tersebut pita yang positif mengandung triterpenoid adalah pita 5a. Selanjutnya dilakukan uji kemurnian terhadap pita 5a. Uji kemurnian isolat triterpenoid dilakukan uji KLT dengan berbagai eluen dan KLT dua dimensi, isolat dikatakan murni apabila memberikan noda tunggal. Uji kemurnian isolat triterpenoid dilakukan dengan berbagai eluen yang dapat dilihat pada gambar 4 .
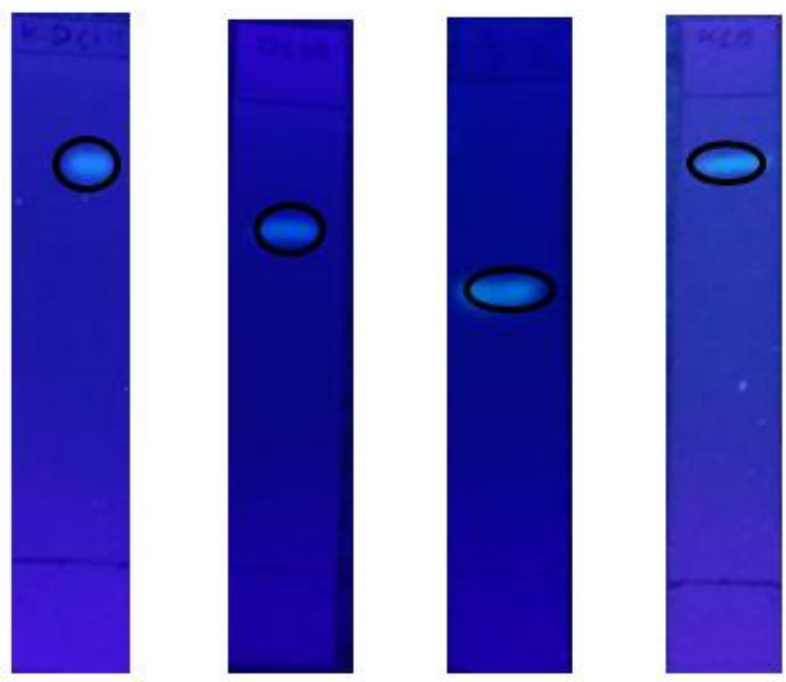

A

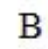

C

D

Gambar 4. Hasil uji kemurnian isolat 5a dengan berbagai eluen pada lampu uv $365 \mathrm{~nm}$

Keterangan : Eluen yang digunakan adalah A. Diklorometana: kloroform ( $1: 1)$; B. Diklorometana; C. Diklorometana : n-heksana (2:1); dan D. Kloroform.
Uji kemurnian juga dilakukan dengan menggunakan KLT dua dimensi. Eluen yang digunakan pada penotolan pertama dan eluen kedua setelah diputar $90^{\circ}$ berbeda. Untuk eluen pertama menggunakan diklorometana dan campuran yang kedua menggunakan kloroform : diklorometana (1:2). Hasil KLT dua dimensi menunjukkan bahwa isolat triterpenoid diduga telah murni karena menunjukkan satu noda yang dapat dilihat pada gambar 5 .

\section{2}

1

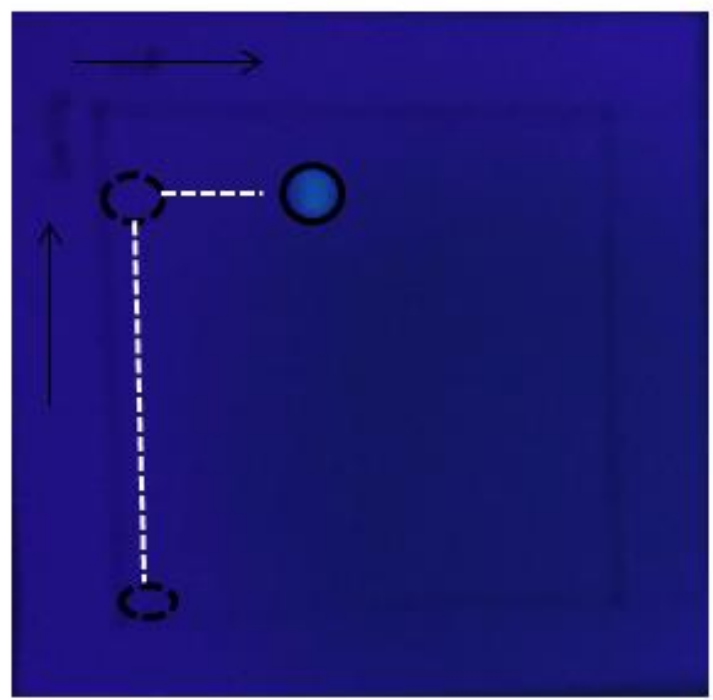

Gambar 5. Hasil KLT dua dimensi isolat triterpenoid dengan eluen 1. Diklorometana dan 2. Kloroform : diklorometana (1:2) pada lampu uv $365 \mathrm{~nm}$

Isolat triterpenoid diidentifikasi menggunakan GCMS, untuk mengetahui perkiraan struktur senyawa triterpenoid pada isolat. Data kromatogram isolat ditampilkan pada Gambar 6.

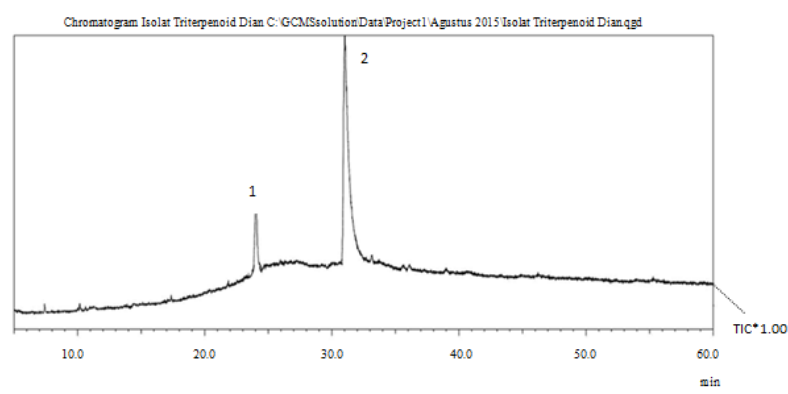

Gambar 6. Kromatogram isolat triterpenoid rimpang lengkuas merah

Hasil analisis menggunakan GC menunjukkan bahwa isolat belum murni dengan adanya 2 puncak dan waktu retensi yang berbeda. Puncak pertama memiliki waktu retensi 24,850 menit dengan kelimpahan sebesar $15,94 \%$. Berdasarkan data yang diperoleh dari database GC-MS, Spektogram massa isolat puncak pertama ditampilkan pada Gambar 7, sedangkan spektogram massa senyawa Olean-12-en-28-al pada database GCMS ditampilkan pada Gambar 8. 


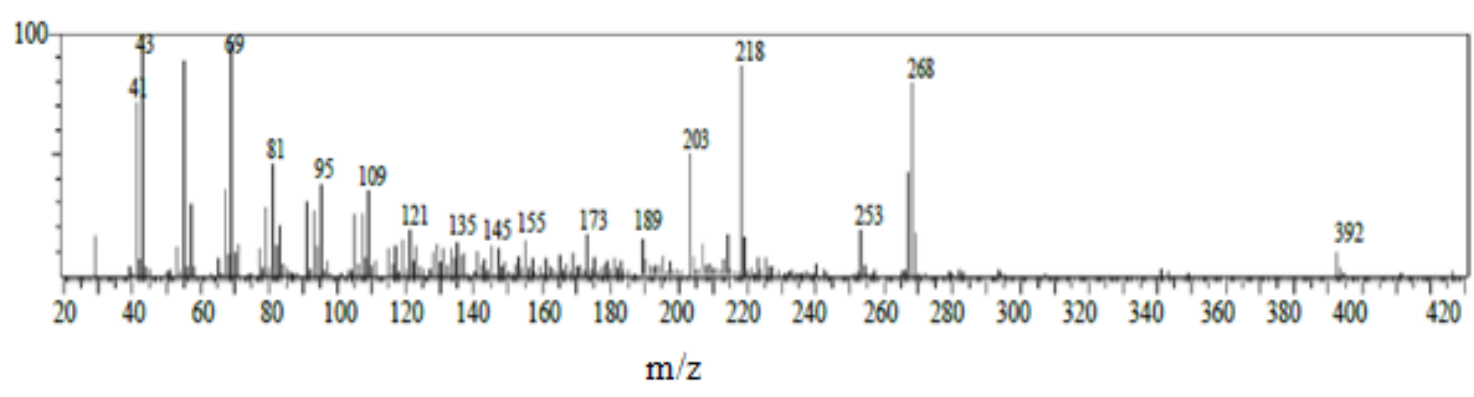

Gambar 7. Spektogram massa isolat puncak pertama

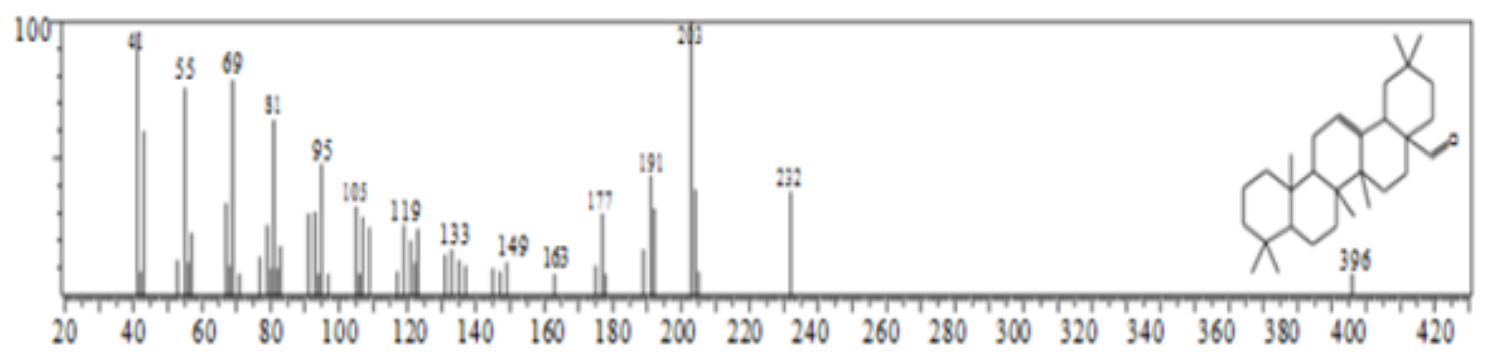

$\mathrm{m} / \mathrm{z}$

Gambar 8. Spektogram massa senyawa Olean-12-en-28-al pada database

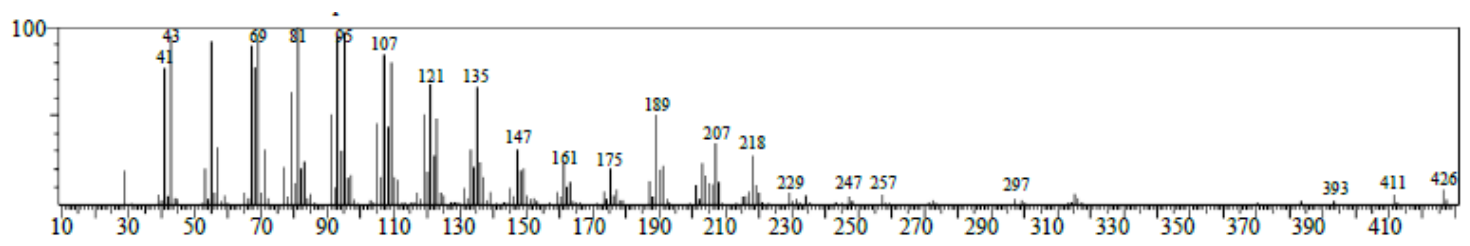

Gambar 9 Spektogram massa isolat puncak kedua

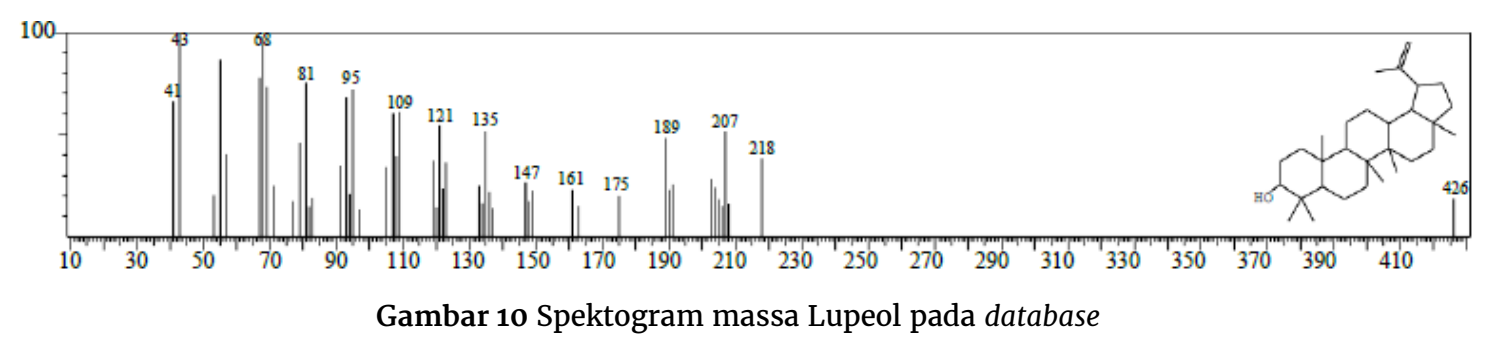

Senyawa puncak pertama pada database GC-MS senyawa diduga merupakan senyawa Olean-12-en-28al dengan similarity index $68 \%$. Senyawa puncak pertama memiliki kelimpahan dan similarity index lebih kecil dari senyawa puncak kedua, sehingga senyawa puncak kedua yang merupakan senyawa terbesar isolat dianalisis lebih lanjut untuk mengetahui struktur senyawanya. Senyawa pada puncak kedua memiliki waktu retensi 31,053 menit dengan kelimpahan sebesar $86,04 \%$. Berdasarkan hasil yang diperoleh dari database, Spektogram massa isolat puncak kedua ditampilkan pada Gambar 9, sedangkan spektogram massa senyawa Lupeol pada database GC-MS ditampilkan pada Gambar 10.

Spektrum massa senyawa puncak kedua memiliki berat molekul sebesar $426 \mathrm{~g} / \mathrm{mol}$ menunjukkan pola fragmentasi sebagai berikut: $\mathrm{m} / \mathrm{z}$ 426[ $\left.\mathrm{M}^{+}\right]$; 411; 393; 257; 218; 207; 189; 175; 161; 147; 135; 121; 107; 95; 81; 69; 43; 41. Spektogram isolat dan senyawa dari database menunjukkan berat molekul dan pola fragmentasi yang mirip dengan similarity index $91 \%$ dengan Lupeol, diduga senyawa isolat dan senyawa dari database identik. Penelitian oleh Sravani dkk. [9] melaporkan telah berhasil mengisolasi Lupeol dari famili Zingiberaceae. Berdasarkan analisis data di atas diusulkan senyawa hasil isolasi adalah senyawa golongan triterpenoid yaitu Lupeol.

\section{Fabrikasi Nanopartikel Ekstrak $\boldsymbol{n}$-heksana}

Pembuatan nanopartikel ekstrak n-heksana menggunakan metode sonikasi bertujuan untuk mengetahui ukuran ekstrak yang telah berukuran nano menggunakan alat PSA, serta membandingkan kemampuan bioaktivitasnya sebelum dan setelah berukuran nano. Ukuran nanopartikel ekstrak nheksana yang dihasilkan dari fabrikasi dapat ditentukan. Hasil pengukuran menggunakan PSA dapat dilihat pada gambar 11. 


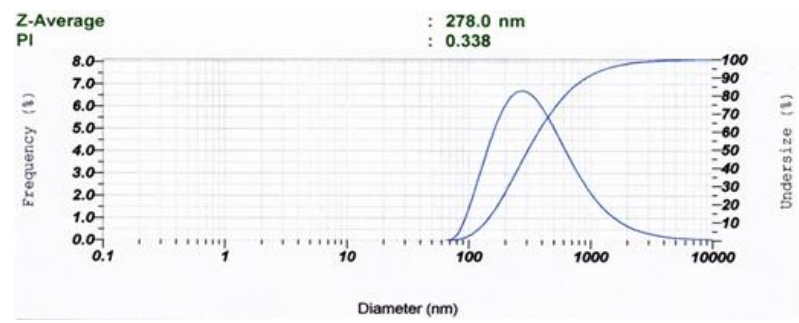

Gambar 11. Hasil analisis menggunakan PSA

Berdasarkan analisis menggunakan PSA, terdapat satu puncak yang menunjukkan adanya satu kelompok distribusi persebaran partikel (monodisperse). Dari hasil grafik di atas, berdasarkan perhitungan rata-rata (Z-Average) diketahui bahwa ukuran rata-rata distribusi nanopartikel ekstrak $n$-heksana adalah 278,0 nm dengan frekuensi $6,706 \%$ dan prosentase kumulatif sebesar 44,706 \%. Hasil ukuran rata-rata distribusi partikel ekstrak $n$-heksana adalah 278,0 nm, sehingga dari ukuran tersebut belum didapatkan ukuran partikel dalam orde nanometer yaitu dari 1-100 nm. Hal ini kemungkinan dikarenakan waktu yang digunakan dalam proses sonikasi kurang lama yang menyebabkan ukuran partikel masih besar.

\section{Uji Sitotoksisitas}

Hasil uji sitotoksisitas ekstrak n-heksana dan nanopartikel ekstrak $n$-heksana dapat dilihat pada tabel 1.

Tabel 1. Hasil uji sitotoksisitas ekstrak $n$-heksana dan nanopartikel ekstrak $n$-heksana lengkuas merah

\begin{tabular}{|c|c|c|c|c|c|c|c|c|}
\hline \multirow{2}{*}{ Sampel } & \multirow{2}{*}{$\begin{array}{c}\text { Konsen- } \\
\text { trasi } \\
\text { (ppm) }\end{array}$} & \multirow{2}{*}{$\begin{array}{l}\text { Nau- } \\
\text { philus } \\
\text { Uji }\end{array}$} & \multicolumn{2}{|r|}{1} & \multicolumn{2}{|r|}{2} & \multicolumn{2}{|r|}{3} \\
\hline & & & Mati & Hidup & Mati & Hidup & Mati & Hidup \\
\hline Kontrol & 0 & 30 & 0 & 10 & 0 & 10 & 0 & 10 \\
\hline \multirow{3}{*}{$\begin{array}{l}\text { Ekstrak n- } \\
\text { heksana }\end{array}$} & 10 & 30 & 3 & 7 & 3 & 7 & 2 & 8 \\
\hline & 100 & 30 & 5 & 5 & 5 & 5 & 3 & 7 \\
\hline & 1000 & 30 & 10 & 0 & 10 & 0 & 10 & 0 \\
\hline \multirow{3}{*}{$\begin{array}{l}\text { Nanopartikel } \\
\text { ekstrak n- } \\
\text { heksana }\end{array}$} & 10 & 30 & 4 & 6 & 3 & 7 & 3 & 7 \\
\hline & 100 & 30 & 7 & 3 & 5 & 5 & 6 & 4 \\
\hline & 1000 & 30 & 10 & 0 & 10 & 0 & 10 & 0 \\
\hline
\end{tabular}

Berdasarkan data yang diperoleh, hasil analisis probit aktivitas sitotoksik ekstrak n-heksana dan nanopartikel ekstrak $n$-heksana menggunakan program SPSS menunjukkan nilai $\mathrm{LC}_{50}$ berturut-turut sebesar 109,668 ppm dan 86,783 ppm. Hasil yang diperoleh pada nanopartikel ekstrak $n$-heksana memiliki nilai $\mathrm{LC}_{50}$ yang lebih kecil dibandingkan ekstrak $n$-heksana yang berukuran bulk. Hal ini disebabkan senyawa yang berukuran nano memiliki luas permukaan yang kecil sehingga akan mengalami peningkatan kemampuan bioaktivitas karena adanya suatu pengaruh, partikel akan naik ke permukaan ketika materi berukuran 1-100 $\mathrm{nm}$, sehingga larutan akan dipengaruhi oleh sifat-sifat permukaaannya yaitu ukuran dan bentuk bukan komposisi larutannya [10].

\section{Kesimpulan}

Hasil analisis MS isolat triterpenoid dari ekstrak nheksana rimpang lengkuas merah (Alpinia purpurata) terdapat senyawa triterpenoid yang memiliki berat molekul $426 \mathrm{~g} / \mathrm{mol}$ diduga merupakan triterpenoid Lupeol. Sintesis nanopartikel ekstrak n-heksana rimpang lengkuas merah dapat dilakukan dengan metode sonikasi dihasilkan partikel berukuran 278,0 nm. Nanopartikel ekstrak $n$-heksana memiliki aktivitas sitotoksik lebih besar daripada senyawa bulk nya, hal ini ditunjukkan hasil LC $_{50}$ ekstrak $n$-heksana dan nanopartikel ekstrak $n$-heksana berturut-turut sebesar 109,668 ppm dan 86,783 ppm.

\section{Daftar Pustaka}

[1] W. John Kress, Ai-Zhong Liu, Mark Newman, QingJun Li, The molecular phylogeny of Alpinia (Zingiberaceae): a complex and polyphyletic genus of gingers, American journal of botany, 92, 1, (2005) 167-178 http://dx.doi.org/10.3732/ajb.92.1.167

[2] S. Ghosh, L. Rangan, Alpinia: the gold mine of future therapeutics, 3 Biotech, 3, 3, (2013) 173-185 http://dx.doi.org/10.1007/s13205-012-0089-x

[3] Eric Wei Chiang Chan, Siu Kuin Wong, Phytochemistry and pharmacology of ornamental gingers, Hedychium coronarium and Alpinia purpurata: a review., Journal of Integrative Medicine, 13, 6, (2015) 368-379 http://dx.doi.org/10.1016/S2095-4964(15)60208-4

[4] Enock Kiage Oirere, Palanirajan Anusooriya, Chinthamony Arul Raj, Velliyur Kanniappan Gopalakrishnan, Phytochemical Analysis of $\mathrm{N}-$ Hexane Leaf Extract of Alpinia Purpurata (Vieill.) K. Schum Using Uv-Vis, FTIR and GC-MS, International Journal of Pharmacy and Pharmaceutical Sciences 7, 8, (2015) 387-389

[5] R. Kelmani Chandrakanth, C. Ashajyothi, A. K. Oli, C. Prabhurajeshwar, Potential Bactericidal Effect of Silver Nanoparticles Synthesised from Enterococcus Species, Oriental Journal of Chemistry, 30, 3, (2014) 1253-1262 http://dx.doi.org/10.13005/ojc/300341

[6] Inbar Yariv, Anat Lipovsky, Aharon Gedanken, Rachel Lubart, Dror Fixler, Enhanced pharmacological activity of vitamin $\mathrm{B}(1)(2)$ and penicillin as nanoparticles, International journal of nanomedicine, 10, 1, (2015) 3593-3601 https://doi.org/10.2147/IJN.S82482

[7] Norman R. Farnsworth, Biological and Phytochemical Screening of Plants, Journal of Pharmaceutical Sciences, 55, 3, 225-276 10.1002/jps.2600550302

[8] M. J. Moshi, E. Innocent, J. J. Magadula, D. F. Otieno, A. Weisheit, P. K. Mbabazi, R. S. Nondo, Brine shrimp toxicity of some plants used as traditional medicines in Kagera Region, north western Tanzania, Tanzania journal of health research, 12, 1, (2010) 63-67

[9] T. Sravani, Padmaa M. B. Paarakh, A. Vedamurthy, Isolation of Phytoconstituents from the rhizomes of Hedychium spicatum Buch. Ham, Journal of Pharmacy Research, 5, 1, (2012) 526

[10] Stephanie M Reimann, Matti Manninen, Electronic structure of quantum dots, Reviews of Modern Physics, 74, 4, (2002) 1283 